\title{
Clinical development of nitisinone for alkaptonuria (developakure) - a rare disease clinical trials design
}

\author{
Eftychia Eirini Psarelli ${ }^{1 *}$, Trevor Cox ${ }^{1}$, Lakshminarayan Ranganath ${ }^{2}$ \\ From 2nd Clinical Trials Methodology Conference: Methodology Matters \\ Edinburgh, UK. 18-19 November 2013
}

\begin{abstract}
Alkaptonuria (AKU) is an orphan inherited homogentisate dioxygenase enzyme deficiency resulting in accumulation of homogentisic acid (HGA). HGA is converted to a black pigment polymer known as ochronosis that causes tissue damage affecting many tissues including joints and heart, with significant poor quality of life. The DevelopAKUre project is a Europe-wide collaboration to study the efficacy and safety of nitisinone as a potential treatment in three clinical studies. The first is a phase 2 dose-response study (SONIA 1) which will determine the optimal dose of nitisinone that decreases HGA levels. The second is a phase III efficacy study (SONIA 2) based on the optimal dose and the third is a cross-sectional study (SOFIA) that will define the age that treatment should begin after determining the onset of ochronosis. Details and rationale of the SONIA 2 design will be described, with special attention to issues arising from the rarity of the disease.
\end{abstract}

\footnotetext{
Authors' details

${ }^{1}$ University of Liverpool, Liverpool, Merseyside, UK. ${ }^{2}$ Royal Liverpool

University Hospital, Liverpool, Merseyside, UK.
}

Published: 29 November 2013

doi:10.1186/1745-6215-14-S1-P29

Cite this article as: Psarelli et al: Clinical development of nitisinone for alkaptonuria (developakure) - a rare disease clinical trials design. Trials 2013 14(Suppl 1):P29.

'University of Liverpool, Liverpool, Merseyside, UK

Submit your next manuscript to BioMed Central and take full advantage of:

- Convenient online submission

- Thorough peer review

- No space constraints or color figure charges

- Immediate publication on acceptance

- Inclusion in PubMed, CAS, Scopus and Google Scholar

- Research which is freely available for redistribution

\footnotetext{
Full list of author information is available at the end of the article
}

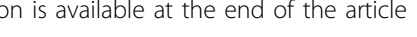

